\title{
Bentuk-Bentuk Perampingan dan Harmonisasi Regulasi
}

\author{
Ibnu Sina Chandranegara \\ Fakultas Hukum Universitas Muhammadiyah Jakarta \\ Jln. KH. Ahmad Dahlan, Cirendeu, Jakarta Selatan, 15419 \\ ibnusinach@gmail.com
}

Received: 10 Juli 2019; Accepted: 11 Agustus 2019; Published: 17 Februari 2020

DOI: 10.20885/iustum.vol26.iss3.art1

\begin{abstract}
Since the reformation era, the number of laws and regulations has continued to increase. In the period 2000-2017 there have been 35,901 regulations. The highest number is Regional Regulation (Perda), which has reached 14,225 Perda. Followed by Ministerial Regulation (Permen) as many as 11,873 regulations. While on the third place, sit 3,163 non-ministerial regulations. This research has the main objective of finding the best alternative policy to simplify and rearrange the regulations as an agenda for the law reform. This is a normative juridical research. The data used are secondary data that includes primary and secondary legal material in the form of relevant laws and regulations used as samples as examples of regulations that are out of sync, incoherent, and potentially overlapping. The results concluded that the arrangement of the regulations can be carried out on three sectors, which are the simplification of regulations, reconceptualization in order to understand the regulatory requirements, and creating synergies amongst the the law-makers.
\end{abstract}

Keywords: Downsizing of regulations; harmonization; laws and regulations

\section{Abstrak}

Sejak reformasi, jumlah peraturan perundang-undangan terus meningkat. Dalam kurun 2000-2017 terdapat 35.901 peraturan. Jumlah terbanyak adalah Peraturan Daerah (Perda) yaitu 14.225 Perda. Disusul dengan Peraturan Menteri (Permen) 11.873 Permen. Di tempat ketiga diduduki peraturan lembaga non kementerian 3.163 peraturan. Penelitian ini memiliki tujuan utama yaitu menemukan pilihan kebijakan dalam upaya menyederhanaan dan penataan regulasi sebagai agenda reformasi hukum. Penelitian ini merupakan penelitian yuridis normatif. Data yang digunakan adalah data sekunder yang meliputi bahan hukum primer dan sekunder berupa peraturan perundangan yang relevan digunakan sebagai sampel sebagai contoh regulasi yang tidak sinkron, tidak koheren, dan berpotensi tumpang tindih. Hasil penelitian menyimpulkan bahwa penataan regulasi dapat dilakukan terhadap tiga sector, yaitu simplifikasi regulasi, rekonseptualisasi pemahaman mengenai kebutuhan regulasi, dan penciptaan sinergi antar pembentuk regulasi.

Kata-kata Kunci : Perampingan regulasi; harmonisasi; peraturan perundangundangan 


\section{Pendahuluan}

Persoalan "bawaan” negara hukum adalah potensi disharmonis regulasi yang mengakibatkan apa yang disebut Richard Susskind sebagai hyper regulations ${ }^{1}$ atau istilah yang kemudian populer disebut obesitas hukum. ${ }^{2}$ Selain meningkatnya peran pengadilan dalam menentukan validitas setiap regulasi maupun kebijakan negara, ${ }^{3}$ ternyata penyusunan regulasi yang dilakukan secara tidak terstruktur dan tidak sistematis namun masif merupakan bom waktu bagi penyelenggaraan negara hukum yang demokratis.

Kurun waktu 2000-2017 terdapat 35.901 peraturan, jumlah terbanyak adalah Peraturan Daerah (Perda) yaitu sebanyak 14.225 Perda, disusul dengan Peraturan Menteri (Permen) sebanyak 11.873 Permen, dan di tempat ketiga diduduki peraturan lembaga non kementerian sebanyak 3.163 peraturan. ${ }^{4}$ Masih tercatat pula peraturan peninggalan Penjajah Belanda sebanyak 36 peraturan. ${ }^{5}$ Jumlah kuantitas yang demikian itu tidak berjalan lurus dengan kualitas regulasi. Hal ini nampak dari banyaknya kaidah-kaidah hukum yang timbul dari proses pengujian

\footnotetext{
${ }^{1}$ Richard Susskind menguraikan "By that I meant we are all governed today by a body of rules and laws that are so complex and so large in extent that no one can pretend to have mastery of them all. I argued then that hyper-regulation means not that there is too much law, by some objective standard, but that there is too much law given our current methods of managing it." Richard Susskind, "Legal Informatics: a Personal Appraisal of Context And Progress", European Journal of Law and Technology, Vol. 1, No 1, 2010, hlm. 90-92

2 Istilah obesitas hukum berkembang dalam focus group discussion 'Penyusunan Program dan Strategi Reformasi Regulasi dalam Rangka Memperkuat Substansi dan Operasionalisasi UU Nomor 12 Tahun 2011' yang digelar oleh Kementerian Hukum dan HAM di Bogor, tanggal 26-28 Oktober 2016. Pertemuan tersebut dihadiri Sunaryati Hartono, Bagir Manan, Hibnu Nugroho, Herowati Poesoko, Widodo Ekatjahjana, Susi Dwi Harijanti, Benny Riyanto, Barda Nawawi, Enny Nurbaningsih, Triana Ohoiwutun, Yenti Garnasih dan Yohanes Usfunan. Adapun dari pemerintah hadir dan memimpin langsung Yasonna Laoly, yang memimpin langsung FGD dan Kepala Staf Kepresidenan Teten Masduki.

3 Kecenderungan yang semacam ini sesungguhnya telah disinggung oleh Dejonghe Matthias yang menyebutnya fenomena countermajoritarian difficulty, dengan disediakannya mekanisme judicial review maka akan mendorong segala pengujian validitas kebijakan regulasi negara melalui peradilan. Hal ini sebagaimana yang diungkapkan "Judicial review is countermajoritarian because it allows judges to thwart the will of the majority. It enables decisions by the legislature to be overturned by a small minority, through judgments". Dejonghe Matthias, Constitutional Courts: Democracy vs. Juristocracy?, Disertasi, Fakultas Hukum Universitas Genht, Brussel, 2015, hlm. 4-5

${ }_{4}^{4}$ Pelacakan sumber data terkait ini dapat meninjau situs direktori http://www.peraturan.go.id di bawah pengelolaan Sistem Informasi Direktoran Jenderal Peraturan Perundang-undangan. Direktori yang diluncurkan Maret 2017 berfungsi sebagai: (1) sarana penyebarluasan seluruh naskah peraturan perundang-undangan tingkat pusat, baik UU, Perpu, PP, Perpres sampai dengan peraturan menteri/peraturan lainnya; (2) sarana memfasilitas partisipasi publik dalam penyusunan peraturan. Dalam situs web ini tersedia dokumen rancangan peraturan maupun informasi terkait pembentukan peraturan perundang-undangan (tahapan dalam pembentukan suatu peraturan perundang-undangan) serta fitur yang memungkinkan masyarakat memberikan masukan secara langsung terkait suatu rancangan peraturan yang tengah disusun maupun rancangan program legislasi; (3) sarana monitoring kinerja legislasi, baik monitoring atas penyelesaian target penyusunan peraturan setiap tahunnya maupun target pengundangan peraturan pelaksana yang diamanatkan oleh suatu peraturan.

${ }^{5}$ Sunaryati Hartono, Analisis dan Evaluasi Peraturan Perundang-undangan Peninggalan Kolonial (Belanda dan Jepang), Kementerian Hukum dan Hak Asasi Manusia, Jakarta, 2014, hlm. 21-57
} 
norma di kekuasaan kehakiman. Tercatat, hingga Maret 2017 terdapat 802 putusan Mahkamah Konstitusi, 203 Putusan Mahkamah Agung, dan kaidah hukum melalui menafsiran hukum seperti yang terdapat dalam putusan pengadilan niaga yang berjumlah 168 putusan. ${ }^{6}$ Dengan demikian, nampak bahwa penerbitan regulasi di Indonesia masih belum sepenuhnya terencana. Apabila masalah penerbitan regulasi tidak segera diselesaikan, maka tentu akan berakibat kontraproduktif dengan upaya meningkatkan pergerakan dan pertumbuhan ekonomi.7 Karena gemuknya regulasi bahkan mengakibatkan Indonesia berada di posisi ke-6 sebagai negara ramah investasi dalam regional ASEAN.8 Parahnya, problem ini seolah tidak terselesaikan dari tahun ke tahun sehingga regulasi kian menumpuk dan tak terkendali meskipun dalam sejarah kebijakan penataan regulasi yang dimaksudkan untuk mencapai tujuan kesejahteraan kerap dilakukan. ${ }^{9}$

\footnotetext{
${ }^{6}$ Rekapitulasi Pengujian UU yang dilakukan oleh Mahkamah Konstitusi secara transparan dapat ditinjau pada situs informasi (http://www.mahkamahkonstitusi.go.id/index.php?page=web.RekapPUU\&menu=5) sedangkan untuk Pengujian peraturan perundang-undangan yang dilakukan oleh Mahkamah Agung dapat di tinjau pada situs informasi perkara (https://putusan.mahkamahagung.go.id/ditjen/tun)

7 Masnur Tiurmaida Malau, “Aspek Hukum Peraturan dan Kebijakan Pemerintah Indonesia Menghadapi Liberalisasi Ekonomi Regional: Masyarakat Ekonomi ASEAN 2015”, Jurnal Rechtsvinding, Vol 3, No 2 Tahun 2014, hlm. 171-172

${ }^{8}$ Darminto Hartono dan Soekotjo Hardiwinoto, "Legal Perspective on Asean Economic Community," Diponegoro Law Review, Vol 3, Number 2, October 2018, hlm. 216-218

${ }_{9}^{9}$ Walaupun belum dilakukan secara sistematis, Reformasi Regulasi sudah pernah dilakukan di Indonesia. Upaya tersebut dilakukan pada sektor tertentu atau sebagai respon terhadap situasi tertentu. Pada 1983, misalnya, ketika terjadi over-regulated terhadap sektor perbankan yang mengakibatkan kondisi stagnan dan hilangnya inisiatif perbankan, Bank Indonesia (BI) melakukan modernisasi perbankan sesuai dengan tuntutan masyarakat, dunia usaha, dan kehidupan ekonomi pada periode tersebut. Deregulasi dimulai dengan penghapusan pagu kredit; bank bebas menetapkan suku bunga kredit, tabungan, dan deposito; serta menghentikan pemberian Kredit Likuiditas Bank Indonesia (KLBI) kepada semua bank, kecuali untuk jenis kredit tertentu yang berkaitan dengan pengembangan koperasi dan ekspor. Tahap awal deregulasi tersebut berhasil menumbuhkan iklim persaingan antarbank. Pada 1988, dalam rangka membuka izin usaha bank baru yang telah dihentikan sejak 1971, pemerintah melakukan deregulasi perbankan dengan mengeluarkan Paket Kebijakan 27 Oktober 1988 (Pakto 88). Hanya dengan modal Rp. 10 miliar seorang pengusaha sudah bisa membuka bank baru. Bank-bank asing lama dan baru pun diizinkan membuka cabangnya di enam kota. Bahkan, bentuk patungan antarbank asing dengan bank swasta nasional pun diizinkan. Reserve requirement bank lokal dari 15 persen menjadi 2 persen. Kebijakan Pakto tersebut menyebabkan peningkatan uang yang beredar di pasar. Dengan kata lain, kebijakan Pakto 88 merupakan kebijakan agresif untuk ekspansi. Dengan pelbagai kemudahan melalui Pakto 88, jumlah bank komersial naik 50 persen dari 111 bank pada Maret 1989 menjadi 176 bank pada Maret 1991. Kemudian, pada 1993, untuk menarik minat investor menanamkan modalnya di Indonesia, pemerintah mengeluarkan paket deregulasi yang dikenal dengan Paket Oktober 1993 (Pakto 1993). Paket ini dimaksudkan untuk memudahkan investor asing menanamkan modalnya di Indonesia. Pakto 1993 tersebut mengatur lima bidang usaha, yaitu: (1) Bidang Ekspor, (2) Bidang Penanaman Modal Asing, (3) Bidang Perizinan Untuk Investasi, (4) Bidang Kesehatan, dan (5) Bidang Penyederhanaan Prosedur Analisa Dampak Lingkungan (AMDAL). Diani Sadiawati, et al. Strategi Nasional Reformasi Regulasi: Mewujudkan Regulasi yang Tertib dan Sederbana, Kementerian Perencanaan dan Pembangunan Nasional/ Bappenas, Jakarta, 2015 hlm. 28-29
} 


\section{Rumusan Masalah}

Penelitian ini disusun untuk menjawab satu rumusan permasalahan yaitu, langkah-langkah apa sajakah yang dapat dilakukan untuk merampingkan jumlah dan harmonisasi regulasi?

\section{Tujuan Penelitian}

Penelitian ini memiliki tujuan utama yaitu menemukan pilihan kebijakan yang termasuk di dalamnya kebijakan non hukum, dalam upaya menyederhanaan dan penataan regulasi sebagai agenda reformasi hukum.

\section{Metode Penelitian}

Penelitian ini merupakan penelitian yuridis normatif. Data yang digunakan adalah data sekunder yang meliputi bahan hukum primer dan sekunder berupa peraturan perundangan yang relevan digunakan sebagai sampel regulasi yang tidak sinkron, tidak koheren, dan berpotensi tumpang tindih. Data sekunder diperoleh melalui studi pustaka. Metode pendekatan yang digunakan adalah pendekatan konsep (conceptual approach) dan pendekatan peraturan perundangan (statue approach). Analisis data dilakukan dengan mensistematisasi data-data untuk selanjutnya data-data tersebut digunakan untuk menerjemahkan konsep yang tepat dalam dalam upaya penyederhanaan dan harmonisasi regulasi.

\section{Hasil Penelitian dan Pembahasan}

\section{Upaya Perampingan Jumlah dan Harmonisasi Regulasi}

Simplifikasi regulasi yang dimaksud adalah penyederhanaan regulasi, yaitu cara untuk mengendalikan kuantitas terhadap regulasi yang sedang menjadi hukum positif (sedang berlaku) dalam rangka mewujudkan regulasi yang proporsional. Dalam sejarahnya, kegiatan simplifikasi regulasi di Indonesia memang sudah dikehendaki khususnya setelah disahkannya UUD 1945 pada 18 Agustus 1945. Dekolonialisasi atas regulasi warisan penjajahan merupakan agenda pembangunan hukum nasional yang hingga masa reformasi belum sepenuhnya menemukan garis akhirnya (finish line).

Sulitnya mengubah bentuk/jenis dari masa lampau seperti W.v.S, B.W, HIR, $\mathrm{Rbg}$, dan beragam kaidah yang masih berlaku menjadi permasalahan bawaan yang 
menimbulkan masalah obesitas hukum di kemudian hari. Misalnya, karena diasumsikan peraturan yang lama telah memberikan pengarahan, maka pembentukan peraturan baru menjadi parsial sesuai kebutuhan, sedangkan induk peraturan lamanya belum dicabut. ${ }^{10}$ Akibatnya, muncul dilema maupun egosentrisme kelembagaan akibat penafsiran yang parsial postur regulasi yang demikian itu. Fase dekolonialisasi yang tidak tuntas sebagaimana diuraikan di atas, akan berujung pada program legislasi yang tidak terstruktur dan tidak sistematis namun masif. Oleh karena itu, upaya penataan pertama yang dapat dilakukan adalah dengan melakukan simplifikasi regulasi yakni dengan cara menginventarisasi regulasi yang ada, mengidentifikasi masalah dan pemangku kepentingannya, melakukan evaluasi regulasi yang bermasalah, dan mencabut yang tidak perlu. ${ }^{11}$

Upaya Kementerian Hukum dan HAM (Kemenkumham) yang menyediakan direktori regulasi merupakan modal awal dalam pemetaan postur regulasi yang selanjutnya memasuki tahapan simplifikasi regulasi di bidang-bidang tertentu guna menjamin kepastian hukum. Selanjutnya, tahapan simplifikasi regulasi dimulai sesuai urutan prosesnya, dimulai dengan inventarisasi, lalu identifikasi, analisis dan kemudian rekomendasi. Dari proses ini akan terlihat apakah sebuah peraturan bisa tetap dipertahankan atau diharmonisasi atau justru harus langsung dicabut. Rekomendasi juga bisa mencakup usulan untuk pembuatan regulasi baru jika dibutuhkan. ${ }^{12}$ Oleh karena jumlah regulasi yang banyak, maka simplifikasi regulasi harus bersifat massal dan cepat, sehingga perlu disusun kriteria sederhana dalam melakukan tahapan simplifikasi tersebut. Pada umumnya masalah yang

\footnotetext{
10 Padmo Wahjono, Sistem Hukum Nasional dalam Negara Hukum Pancasila: Pidato Ilmiah pada Peringatan Dies Natalis Universitas Indonesia ke- 33, Rajawali Press, Jakarta, 1983, hlm. 4-8

${ }^{11}$ Kementerian Hukum dan Hak Asasi Manusia, Pengharmonisasian, Pembulatan, dan Pemantapan, Konsepsi Rancangan Peraturan, Perundang-Undangan, Direktorat Jenderal Peraturan Perundang-Undangan, Jakarta, 2010, hlm. 18-20.

${ }^{12}$ Sebanyak 50 persen dari total regulasi yang ada yakni 42.000 sejak tahun 2016 telah berhasil disimplifikasi. Pemerintah sudah mulai melakukan simplifikasi regulasi. Simplifikasi regulasi di bidang perizinan dan investasi dilakukan dengan cara berkoordinasi dengan 20 kementerian/lembaga. Pemilihan $20 \mathrm{~K} / \mathrm{L}$ ini didasarkan pada Instruksi Presiden (Inpres) No. 4 Tahun 2015 tentang Pelaksanaan Pelayanan Terpadu Satu Pintu Pusat di Badan Koordinasi Penanaman Modal (BKPM). Untuk tahun 2016, 324 regulasi telah dicabut dan sebanyak 75 regulasi direvisi. Diani Sadiawati, et al. Strategi Nasional Reformasi Regulasi..., Op. Cit., hlm. 39
} 
dihadapi akan digeneralisasi terhadap kriteria tertentu. Secara umum, menurut

Diani Sadiawati, et. al, permasalahan regulasi diklasifikasi menjadi: ${ }^{13}$

(1) Konflik Regulasi. Konflik yang dimaksud adalah suatu kondisi dimana terdapat pasal atau ketentuan yang nyata-nyata bertentangan dengan peraturan lainnya. Contoh: Pasal 29 ayat (2) dan ayat (3) UU No. 5 Tahun 1960 Tentang Peraturan Dasar Pokok-pokok Agraria (UUPA) yang mengatur bahwa Hak Guna Usaha (HGU) dapat diberikan untuk jangka waktu paling lama 60 tahun dengan Pasal 22 ayat (1) huruf a UU No. 25 Tahun 2007 Tentang Penanaman Modal yang mengatur bahwa HGU dapat diberikan untuk jangka waktu paling lama 95 tahun, dan Pasal 35 ayat (1) dan (2) UUPA yang mengatur bahwa Hak Guna Bangunan (HGB) dapat diberikan untuk jangka waktu paling lama 50 tahun dengan Pasal 22 ayat (1) huruf b Undang Undang Penanaman Modal yang mengatur bahwa HGB dapat diberikan untuk jangka waktu paling lama 80 tahun

(2) Inkonsistensi Regulasi. Inkonsisten yang dimaksud apabila terdapat ketentuan atau pengaturan yang tidak konsisten dalam satu peraturan perundang-undangan beserta turunannya. Contoh: Definisi penanaman modal dalam Pasal 1 angka 1 Undang-Undang No. 25 Tahun 2007 tentang Penanaman Modal (Penanaman modal adalah segala bentuk kegiatan menanam modal, baik oleh penanam modal dalam negeri maupun penanam modal asing untuk melakukan usaha di wilayah negara Republik Indonesia) dengan definisi penanaman modal dalam Pasal 1 angka 1 PP No 1 Tahun 2007 jo. PP No. 62 Tahun 2008 Tentang Fasilitas Pajak Penghasilan untuk Penanaman Modal di Bidang-bidang Usaha Tertentu dan/atau di Daerah-daerah Tertentu (Penanaman modal adalah investasi berupa aktiva tetap berwujud termasuk tanah yang digunakan untuk kegiatan utama usaha, baik untuk penanaman modal baru maupun perluasan dari usaha yang telah ada).

(3) Multitafsir Regulasi. Dikategorikan sebagai multitafsir apabila terdapat ketidakjelasan pada objek dan subjek yang diatur sehingga menimbulkan ketidakjelasan rumusan bahasa (sulit dimengerti) serta sistematika yang tidak jelas. Contoh: Pasal 14 Undang-Undang Nomor 25 Tahun 2007 Tentang Penanaman Modal menyatakan: "Setiap penanam modal berhak mendapat: a. kepastian hak, hukum, dan perlindungan; b. dst ...". Penjelasan Pasal 14 huruf (a) menyatakan bahwa "Yang dimaksud dengan 'kepastian hak' adalah jaminan Pemerintah bagi penanam modal untuk memperoleh hak sepanjang penanam modal telah melaksanakan kewajiban yang ditentukan". Perumusan pasal dan penjelasannya tidak menjawab "hak apa saja" sehingga potensi terjadinya multitafsir sangat besar'.

(4) Tidak operasional. Regulasi dinyatakan tidak operasional apabila regulasi tersebut tidak memiliki daya guna, namun peraturan tersebut masih berlaku atau peraturan tersebut belum memiliki peraturan pelaksana. 
Langkah berikutnya adalah dengan melakukan analisa regulasi dengan menggunakan beberapa kriteria dengan merujuk kepada strategi Kementerian Pembangunan dan Perencanaan Nasional/Bappenas adalah menggunakan kriteria legalitas, kebutuhan, dan situasional. ${ }^{4}$ Kriteria legalitas dan kebutuhan dikembangkan dari teori keberlakuan regulasi, yaitu filosofis, yuridis, dan sosiologis. Aspek filosofis dan yuridis diwakili oleh kriteria legalitas dan aspek sosiologis diwakili oleh kriteria kebutuhan. Sedangkan kriteria situasional adalah kriteria yang dikembangkan untuk mengakomodasi satu isu tertentu, Diani Sadiawati, et al memilih menggunakan kriteria 'user friendly' atau 'ramah urusan'.15 Sebagai contoh, jika bidang yang disimplifikasi adalah bidang pelayanan publik, maka kriteria ramah urusan dapat dikembangkan lebih lanjut, misalnya, dengan sub-kriteria: biaya murah, persyaratan yang tidak memberatkan, dan proses cepat.

Melalui operasionalisasi ketiga kriteria di atas, maka regulasi yang memenuhi kriteria legalitas (tidak bertentangan dengan regulasi lain, baik secara vertikal maupun secara horizontal), kriteria kebutuhan (dibutuhkan oleh masyarakat), dan kriteria ramah urusan dapat dinilai sebagai regulasi yang baik. Dengan melakukan analisis melalui ketiga kriteria tersebut, maka dapat dihasilkan tiga rekomendasi, yaitu: ${ }^{16}$

(1) Regulasi dipertahankan. Regulasi dipertahankan apabila: (1) regulasi tersebut tidak berpotensi konflik dengan regulasi lain terutama yang berkedudukan lebih tinggi, (2) regulasi tersebut dibutuhkan oleh masyarakat maupun oleh penyelenggara negara, dan (3) regulasi tersebut ramah urusan.

(2) Regulasi direvisi. Regulasi direvisi apabila di dalam regulasi tersebut terdapat potensi masalah dan tidak ramah urusan tetapi dibutuhkan oleh masyarakat maupun oleh penyelenggara negara.

(3) Regulasi dicabut. Rekomendasi yang dihasilkan menentukan tindakan lebih lanjut yang harus dilakukan. Jika rekomendasinya adalah regulasi dipertahankan, maka tindak lanjut tidak lagi diperlukan. Apabila rekomendasinya adalah regulasi direvisi atau dicabut, maka tindak lanjut yang diperlukan adalah melakukan langkah-langkah sebagaimana diatur di dalam Undang-Undang Nomor 12 Tahun 2011 yang hingga saat ini masih berlaku.

\footnotetext{
14 Ibid., hlm. 40

${ }^{15}$ Ibid

${ }^{16}$ Ibid., hlm. 41
} 
Salah satu kecenderungan yang bisa dilihat dari perkembangan pembentukan perundang-undangan adalah kerap kali pembentukan regulasi seolah-olah menjadi obat yang paling ampuh untuk mengatasi persoalan yang ada sehingga terlalu banyak persoalan yang ingin diatur, sehingga mengabaikan bahwa masalah sesungguhnya adalah berkenaan dengan penegakkan hukum. Sebagai contoh, untuk mengatasi permasalahan hubungan antar umat beragam, muncul usulan untuk membentuk undang-undang yang mengatur kerukunan antar umat beragama. Contoh lainnya adalah merespon aksi terorisme belakangan, pemerintah menggagas revisi undang-undang anti terorisme. Penyelesaian masalah yang cenderung tidak bisa memisahkan antara reaksi dan respon tersebut, jelas tidak dapat dipungkiri melahirkan pola hyper regulated.

Presiden Joko Widodo dalam banyak kesempatan, kerap mengeluhkan ihwal gemuknya jumlah undang-undang. ${ }^{17}$ Baginya, sepanjang kualitasnya betul-betul baik, tiga atau lima UU cukup dalam satu tahun. Pernyataan ihwal jumlah UU kembali diangkat Presiden Joko Widodo saat bertemu dengan sejumlah kalangan hukum di Istana Negara 22 September 2016.18 Terlepas gemuknya jumlah undangundang yang bertebaran dalam sistem hukum Indonesia, Saldi Isra menguraikan bahwa tidak sepenuhnya masalah yang dihadapi adalah kuantitas undang-undang tersebut. Karena menurutnya, selain masih banyaknya UU atas dasar amanat UUD 1945 yang belum dijalankan, banyaknya masalah sektoral yang nyatanya membutuhkan pemutakhiran regulasi. ${ }^{19}$ Salah satu contohnya, UU No. 23 Tahun

17 Terurai dalam penyampaian pembuka dalam acara dialog "Membangun Ekonomi Indonesia yang Berdaya Saing", di Balai Kartini 30 Maret 2016, Jokowi menyatakan, "DPR tidak usahlah memproduksi UU terlalu banyak". Kompas, 13 Maret 2017

18 Kompas, 13 Maret 2016

19 Saldi Isra mengemukakan "Dalam batas penalaran yang wajar, mengeluhkan banyaknya jumlah UU sebagai penyebab regulasi tak terkendali tidaklah tepat. Apabila harus mengatakan secara jujur, UU yang dihasilkan setiap tahun sangat sedikit ketimbang jumlah yang mestinya diperlukan. Paling tidak, menggunakan kebutuhan dalam satu tahun berdasarkan program legislasi nasional, jumlah UU yang dihasilkan jauh dari memadai. Tambah lagi, apabila dibaca konstitusi, masih banyak UU untuk menjalankan amanat UUD 1945 yang belum dibentuk. Apabila dibandingkan dengan negara-negara lain, jumlah UU yang dihasilkan Indonesia setiap tahun sangat sedikit. Sebagai contoh, Jepang dengan bentangan wilayah dan penduduk yang lebih kecil dibandingkan dengan Indonesia, satu tahun menghasilkan tak kurang dari 100 UU, baik UU yang sama sekali baru maupun hasil revisi. Begitu pula Belanda, dengan wilayah dan penduduk yang berbeda jauh dengan Indonesia, satu tahun negara Kincir Angin itu menghasilkan UU dengan jumlah lebih kurang sama dengan Jepang. Sebagai produk hukum yang merupakan hasil kerja bersama antara presiden dan DPR (juga DPD kalau menyangkut Pasal 22D UUD 1945), jumlah UU yang dihasilkan dalam satu tahun bukanlah masalah dalam isu over-regulated. Bahkan, dalam beberapa tahun terakhir, presiden dan DPR sangat tidak produktif membuat UU. Masalah mendasarnya, UU yang dihasilkan seolah-olah tak terkait dengan UU lain. Padahal, dengan menggunakan pendekatan sistem, tak mungkin pengesahan suatu UU sama sekali tak berkaitan dengan UU yang lain. Pengalaman Jepang, ketika dilakukan reformasi mendasar terhadap 
2014 sebagai pengganti UU No. 32 Tahun 2004 tentang Pemerintahan Daerah berhenti begitu pengesahan. Padahal, sebagai UU yang terkait dengan banyak UU lain (sektoral) dalam penyelenggaraan hubungan pusat dan daerah, tak mungkin perubahan UU No. 32 Tahun 2004 menjadi UU No. 23 Tahun 2014 tak berimplikasi pada revisi UU lainnya. ${ }^{20}$ Dengan uraian pendapat yang demikian itu, menurut Saldi Isra, jumlah UU yang dihasilkan tak begitu relevan untuk dikambinghitamkan ketika membahas over regulated. Masalah sesungguhnya, sejumlah UU memicu persoalan serius, terutama ketidakpastian hukum yang terjadi karena ketidakseriusan dalam melakukan harmonisasi dan sinkronisasi dengan UU lain. Baginya, pada titik ini, menghilangkan egosektoral kementerian/lembaga dalam menentukan substansi UU menjadi keniscayaan. Selain itu, pembahasan di DPR juga harus dilakukan lintas komisi. Selama egosektoral dan pembahasan di DPR tidak diperbaiki, kehadiran UU yang tidak harmonis dan tidak sinkron sulit dihindari. ${ }^{21}$

Maria Farida Indrati mengemukakan sebaliknya, bahwa saat ini banyak materi muatan yang seharusnya cukup diatur lewat peraturan perundangundangan di bawah undang-undang justru dipaksakan diatur dengan undangundang. Padahal seandainya diatur dengan peraturan perundang-undangan di bawah undang-undang, pelaksanaannya menjadi lebih sederhana dan anggaran yang dibutuhkan relatif kecil. ${ }^{22}$ Ann Seidman, Robert B. Seidman, dan Nalin Abeyserkere menjelaskan setidaknya terdapat tiga alasan urgensi pengaturan dalam bentuk undang-undang. Pertama, alasan kebutuhan untuk memerintah, kedua, alasan tuntutan legitimasi dan ketiga, alasan perlunya jaminan perlindungan

UU desentralisasi tahun 2000, perubahan diikuti dengan merevisi tak kurang dari 750 UU lainnya." Kompas, 13 Maret 2017, Saldi Isra, "Merampingkan Regulasi."

${ }^{20} \mathrm{Ibid}$

${ }^{21}$ Ibid

${ }^{22}$ Maria Farida Indrati mengemukakan bahwa pembentukan undang-undang setelah Perubahan UUD 1945 khususnya Pasal 20 dan Pasal 5 ayat (1) menunjukan DPR memang kekuasaan yag lebih besar dalam pembentukan undang-undang dibanding masa sebelumnya. Namun, upaya meningkatkan peran dan fungsi DPR khususnya fungsi legislasi melalui Perubahan UUD 1945, masih menghadapi sejumlah tantangan. Maria lebih jauh mengemukakan setelah melakukan analisis terhadap undang-undang yang dibentuk 1999-2012 (428 undangundang), maka terlihat adanya usaha, bahkan pemaksaan untuk membentuk suatu undang-undang oleh lembaga pembentuknya, yaitu DPR dan Presiden. Permasalahan sederhana dan seharusnya tidak perlu diatur dalam undangundang (karena bukan termasuk materi undang-undang), tetap di paksakan menjadi undang-undang. Maria Farida Indrati, Pengantar dalam Bayu Dwi Anggono, Perkembangan Pembentukan Undang-Undang di Indonesia, Konstitusi Press, Jakarta, 2014, hlm. xii 
HAM. ${ }^{23}$ Alasan kebutuhan untuk memerintah dimaknai sejalan dengan penerapan konsep negara hukum baik dalam tipe negara hukum materiil maupun formil, yang mana dalam negara hukum, hukum tertulis (undang-undang) menjadi dasar bagi tindakan penguasa maupun pengesahan tindakan tersebut. Alasan ini juga menegaskan bahwa pemerintah menjunjung tinggi kebergunaan undang-undang dalam menjalankan roda pemerintahan. ${ }^{24}$ Selanjutnya alasan tuntutan legitimasi. Kebijakan pemerintah yang diformulasikan dalam bentuk undang-undang memberikan pemerintah suatu legitimasi. Legitimasi inilah dibutuhkan pemerintah dan aparaturnya untuk menguatkan posisi kebijakannya ketika berhadapan dengan publik sehingga membutuhkan materi pengaturan berbentuk undang-undang. Dari pendapat tersebut juga dapat dilihat bahwa undang-undang diperlukan untuk mengatur kepentingan umum. Pemerintah menjalankan fungsinya untuk melayani kepentingan umum, sehingga undang-undang yang dibentuk harus memberikan manfaat yang luas bagi masyarakat. ${ }^{25}$ Selanjutnya alasan perlunya jaminan perlindungan HAM merupakan alasan ketiga perlunya peraturan berbentuk undang-undang. Jaminan perlindungan tidak hanya memuat hak apa yang dilindungi, namun juga pembatasan HAM yang merupakan materi muatan undang-undang. ${ }^{26}$

23 Ann Seidman, Robert B. Seidman, dan Nalin Abeyserkere, Penyusunan Rancangan Undang-Undang Dalam Perubahan Masyarakat Yang Demokratis, Elips Departemen Kehakiman dan Hak Asasi Manusia Republik Indonesia, Jakarta, 2002, hlm. 41

${ }^{24}$ Ibid

${ }^{25} \mathrm{Hal}$ ini juga di isyaratkan John Locke dengan mengatakan "the legislative power is put into the hands of divers persons, who duly assembled, have by themselves, or jointly with others, a power to make laws, which when they have done, being separated again, they are themselves subject to the laws they have made; which is a new and near tie upon them, to take care, that they make them for the public good", undang-undang yang dibuat oleh kekuasaan legislatif adalah yang dapat memberikan kebaikan bagi masyarakat. John Locke, Second Treatise of Civil Government, McMaster University Press, Dublin, 1998, hlm. 168

${ }^{26}$ Apabila merujuk kepada Putusan Mahkamah Konstitusi Nomor 2-3/PUU-V/2007, hlm. 412, Mahkamah mengemukakan: "dari perspektif original intent pembentuk UUD 1945, seluruh hak asasi manusia yang tercantum dalam Bab XA UUD 1945 keberlakuannya dapat dibatasi. Original intent pembentuk UUD 1945 yang menyatakan bahwa hak asasi manusia dapat dibatasi juga diperkuat oleh penempatan Pasal 28J sebagai pasal penutup dari seluruh ketentuan yang mengatur tentang hak asasi manusia dalam Bab XA UUD 1945 tersebut. Jadi, secara penafsiran sistematis (sistematische interpretatie), hak asasi manusia yang diatur dalam Pasal 28A sampai dengan Pasal 28I UUD 1945 tunduk pada pembatasan yang diatur dalam Pasal 28J UUD 1945. Sistematika pengaturan mengenai hak asasi manusia dalam UUD 1945 sejalan dengan sistematika pengaturan dalam Universal Declaration of Human Rights yang juga menempatkan pasal tentang pembatasan hak asasi manusia sebagai pasal penutup, yaitu Pasal 29 ayat (2) yang berbunyi, "In the exercise of his rights and freedoms, everyone shall be subject only to such limitations as are determined by law solely for the purpose of securing due recognition and respect for the rights and freedoms of others and of meeting the just requirements of morality, public order and the general welfare in a democratic society." 
Persoalan yang justru berkembang saat ini adalah mengenai batasan ruang lingkup kebutuhan masyarakat yang perlu diatur dalam undang-undang. Sebagai contoh, dalam UU No. 36 Tahun 2009 tentang Kesehatan Pasal 151, disebutkan bahwa "Ketentuan lebih lanjut mengenai upaya kesehatan jiwa diatur dengan Peraturan Pemerintah". Namun, justru muncul UU No. 18 Tahun 2014 tentang Kesehatan Jiwa. Hal yang semacam ini adalah gejala atau peristiwa hukum yang masih sering terjadi, yaitu tidak ada batasan materi muatan dalam pembentukan undang-undang. Selain itu, salah satu fenomena penting di era reformasi adalah maraknya judicial review di Mahkamah Konstitusi, namun pada saat yang bersamaan dihadapkan dengan meningkatnya kuantitas produksi undang-undang yang disahkan oleh DPR. Kuantitas dan kualitas produk tidaklah selalu linier, justru cenderung dipertanyakan melalui pisau judicial review. ${ }^{27} \mathrm{Hal}$ ini menunjukan bahwa meskipun sudah diatur mengenai batasan materi yang dapat diatur menurut UU No. 12 Tahun 2011, namun sayangnya, belum ada batasan lebih lanjut mengenai kebutuhan hukum dalam masyarakat, sehingga bisa menjadi pintu masuk untuk mengatur banyak hal dalam suatu undang-undang.

Berbeda dengan pandangan Maria Farida Indrati, Saldi Isra justru mengemukakan bahwa titik tembak untuk merampingkan regulasi yang terlalu gemuk terletak kepada peraturan perundang-undangan di bawah undangundang. Dengan alur logika bahwa terbatasnya jumlah regulasi dalam bentuk UU yang dihasilkan, maka apabila dirujuk Pasal 7 ayat (1) UU No. 12 Tahun 2011 over regulated berasal dari peraturan pemerintah dan peraturan presiden (perpres). Apabila merujuk kepada Pasal 12 dan 13 UU No. 12 Tahun 2011 yang menegaskan bahwa materi muatan peraturan pemerintah berisi materi untuk menjalankan undang-undang sebagaimana mestinya dan materi muatan perpres berisi materi yang diperintahkan oleh undang-undang, materi untuk melaksanakan peraturan

${ }^{27}$ Bayu Dwi Anggono mencontohkan kecenderungan paksaan pembentukan diantaranya adalah UU yaitu UU No. 12 Tahun 2012 tentang Pendidikan Tinggi, UU No. 16 Tahun 2012 tentang Industri Pertahanan dan UU No. 13 Tahun 2011 tentang Penanganan Fakir Miskin. Pasal 24 ayat (4) UU No. 20 Tahun 2003 tentang Sistem Pendidikan Nasional menetapkan ketentuan mengenai penyelenggaraan pendidikan tinggi diatur lebih lanjut dengan PP. Ketentuan Pasal 4 ayat (1) dan ayat (2) UU No. 5 Tahun 1984 tentang Perindustrian menyebutkan mengenai Industri Pertahanan merupakan materi muatan PP. Pasal 23 UU No. 11 Tahun 2009 tentang Kesejahteraan Sosial mengatur ketentuan lebih lanjut mengenai penanggulangan kemiskinan diatur dengan PP. Bayu Dwi Anggono, Perkembangan Pembentukan Undang-Undang di Indonesia, Konstitusi Press, Jakarta, 2014, hlm. 41 
pemerintah, atau materi untuk melaksanakan penyelenggaraan kekuasaan pemerintahan. Apabila dibaca materi muatan kedua regulasi ini, maka penyelenggaraan pemerintahan akan bertumpu pada peraturan pemerintah dan perpres. Konstruksi yang demikian ini berpotensi mendudukkan peraturan pemerintah atau perpres lebih berposisi sebagai maksud undang-undang yang sesungguhnya (regulation intent) ketika undang-undang belum (sepenuhnya) menjelaskan maksud pembentukan hukum (legal intent). ${ }^{28}$

Penyusunan peraturan pemerintah dan perpres, khususnya berkenaan dengan dasar pembentukan penyelenggaraan pemerintahan, harus terencana dan tidak bersifat reaktif. Sebagai contoh, penerbitan Peraturan Menteri Kelautan dan Perikanan No. 2 Tahun 2015 tentang Larangan Menangkap Ikan Menggunakan Alat Tangkap Cantrang. Penggunaan alat tersebut dianggap tidak ramah lingkungan. Namun, Luhut Binsar Panjaitan selaku Menteri Koordinator Kemaritiman berpandangan lain dan ingin memaksimalkan daya tangkap nelayan, sehingga Peraturan Menteri tersebut diminta untuk dilakukan pembatalan. Keadaan yang demikian ini menunjukkan adanya kelemahan dalam upaya mengintegrasikan wilayah maupun kebijakan-kebijakan dalam rangka penyelenggaraan negara dan pembangunan ke dalam suatu Sistem Regulasi Nasional yang merupakan agregasi dari semua regulasi yang ada.

Selain peraturan pemerintah dan perpres, jenis peraturan menteri juga membawa "kolesterol jahat" dalam gemuknya hukum. Nasir Djamil menguraikan, bahwa dalam rentang 2000 hingga pengujung 2015, pemerintah telah menerbitkan 12.471 regulasi. Dari jumlah tersebut, regulasi yang paling banyak adalah peraturan setingkat menteri, yakni 8.311. Urutan selanjutnya, peraturan pemerintah dengan jumlah 2.446 regulasi. ${ }^{29}$ Ruang untuk pembentukan peraturan menteri dibuka berdasarkan Pasal 8 UU No. 12 Tahun 2011. Meskipun dalam

${ }^{28}$ Dalam praktiknya, terdapat undang-undang yang harus dibatalkan ketika diuji validitas konstitusionalnya dan ternyata sumber inkonstitusionalitasnya berada di tataran peraturan pemerintah atau perpres. Contohnya dalam Pengujian UU No. 7 Tahun 2004 Tentang Sumber Daya Air (UU SDA), Putusan No. 85/ PUU-XI/2013 menyatakan membatalkan secara keseluruhan UU SDA justru menggunakan beberapa PP sebagai alasan inkonstitusionalitas suatu undang-undang, PP tersebut antara lain: PP No. 16 Tahun 2005 tentang Pengembangan Sistem Penyediaan Air Minum, PP No. 20 Tahun 2006 Tentang Irigasi, PP No. 42 Tahun 2008 tentang Pengelolaan Sumber Daya Air, PP No. 43 Tahun 2008 tentang Air Tanah, PP No. 38 Tahun 2011 Tentang Sungai, PP No. 73 Tahun 2013 tentang Rawa. Ibnu Sina Chandranegara, "Purifikasi Konstitusional Sumber Daya Air Indonesia", Jurnal Rechtsvinding, Vol. 5 No. 3, 2016 hlm. 366-367

29 Seputar Indonesia, 12 November 2015, Nasir Djamil, "Setengah Hati Reformasi Regulasi”. 
ketentuan tersebut memberi ruang bagi menteri untuk membentuk peraturan menteri, selain lembaga negara lainnya, akan tetapi jumlah regulasi berbentuk peraturan menteri sangat dominan jumlahnya, yaitu dua pertiga (67 persen) dari semua jumlah produk hukum yang dibentuk jajaran eksekutif sepanjang 20002015. ${ }^{30}$ Padahal, secara konstitusional, dari jajaran eksekutif, menteri hanya pembantu presiden yang membidangi urusan tertentu dalam pemerintahan.

Penanggulangan terbitnya peraturan menteri yang masif, Saldi Isra menguraikan solusi penataan regulasi yakni, ${ }^{31}$ pertama, mempersempit ruang untuk membentuk peraturan menteri. Cara yang paling sederhana adalah menghilangkan frasa "dibentuk berdasarkan kewenangan" sebagaimana termaktub dalam Pasal 8 ayat (2) UU No. 12 Tahun 2011. Kedua, sekalipun dibuka ruang berdasarkan delegasi undang-undang, peraturan pemerintah dan perpres, namun dalam membentuk peraturan menteri, ruang tersebut harus diikuti dengan kewajiban yaitu setiap rancangan peraturan menteri harus mengikuti proses harmonisasi di Kemenkumham. Selain kedua penyelesaian tersebut, penulis menambahkan solusi penyelesaian yakni dengan cara mengintegrasikan kelembagaan pembentuk regulasi yang ada selama ini. Pembentukan peraturan menteri tanpa sinergi jelas akan melemahkan ketentuan yang ada di atasnya. Oleh karena itu, penyelesaian persoalan pemerintahan yang sektoral tidak perlu semuanya diselesaikan melalui pembentukan regulasi. Keinginan memperoleh legitimasi melalui regulasi dan tingginya keyakinan bahwa pembentukan regulasi menjadi solusi menyelesaikan masalah sosial akan menyebabkan tingginya produksi regulasi.

Pengujian kualitas regulasi melalui metode Regulatory Impact Analysis (RIA) yang sedang dikembangkan oleh Kementerian PPN/Bapennas, sebenarnya dapat menjadi solusi untuk menilai kualitas suatu regulasi. ${ }^{32}$ Regulatory Impact Analysis (RIA) atau Analisis Dampak Kebijakan pada awalnya merupakan alat kebijakan yang digunakan secara luas di negara-negara anggota OECD (Organization for

${ }^{30}$ Saldi Isra, Merampingkan Regulasi..., Op. Cit

${ }^{31}$ Ibid.

32 Suska, "Prinsip Regulatory Impact Assessment dalam Proses Penyusunan Peraturan PerundangUndangan Sesuai UU Nomor 12 Tahun 2011”, Jurnal Konstitusi, Vol 9, No 2, 2012, hlm. 358 
Economic, Co-operation and Development). Dalam hal ini, RIA meneliti dan mengukur kemungkinan manfaat, biaya dan dampak peraturan baru atau diubah. RIA juga menyediakan alat untuk pembuat keputusan dengan data empiris dengan sebuah kerangka komprehensif yang dapat digunakan untuk menilai pilihan dan konsekuensi keputusan yang dimiliki. RIA digunakan untuk mendefinisikan masalah dan untuk memastikan bahwa tindakan pemerintah itu dibenarkan dan sesuai. $^{33}$

Salah satu dari sekian permasalahan, namun sangat mendasar sifatnya adalah masih terjadinya disharmoni antara penyusunan kebijakan (policy making) dengan penyusunan regulasi yang dibutuhkan (regulatory making) untuk melaksanakan kebijakan serta memastikan ketersediaan pendanaan pembangunan baik di tingkat pusat dan daerah serta pelibatan masyarakat dan dunia usaha. Secara kuantitatif, pembentukan regulasi mulai dari pusat sampai dengan daerah sudah over regulated, menimbulkan tumpang tindih, disharmoni, konflik, multitafsir baik secara vertikal (hierarki) maupun secara horisontal. Dari segi pembentukan legislasi saja, disharmoni antara policy making dengan regulatory making terlihat dari evaluasi terhadap perencanaan pembentukan undang-undang yang direncanakan dalam Daftar Rancangan Undang-Undang (RUU) Prioritas Prolegnas 2010-2014 dan kebutuhan RUU yang direncanakan dalam RPJMN 2010-2014. ${ }^{34}$ Prolegnas 20102014 menetapkan 258 RUU untuk diselesaikan, namun RPJMN 2010-2014 hanya merencanakan 29 RUU. RUU yang sejalan antara RPJMN 2010-2014 dan Prolegnas 2010-2014 adalah sejumlah 20 RUU. Kondisi demikian memperlihatkan tidak sinerginya antara perencanaan kebijakan pembangunan regulasi dengan perencanaan pembentukan regulasi yang seharusnya memperlihatkan sinergi antara peran Negara sebagai regulator dan peran Negara sebagai operator. ${ }^{35}$

\footnotetext{
${ }^{33}$ Andreja Marušić dan Branko Radulović, Regulatory Impact Analysis (RIA) Manual, USAID Montonegro, Podgorica, 2011, hlm. 14-15

34 Prolegnas 2010-2014 memuat RUU Prioritas sejumlah 258 RUU, sedangkan dalam RPJMN 2010-2014 memuat 29 RUU. Kesenjangan yang sangat tinggi antara perencanaan kebijakan pembentukan regulasi dalam RPJMN 2010-2014 dengan perencanaan pembentukan regulasi dalam Prolegnas 2010-2014 menimbulkan pertanyaan, apakah PROLEGNAS yang selama ini dianggap sebagai prioritas dari Lembaga Legislatif dan pemerintah sebagai perwujudan Lembaga Eksekutif benar-benar ditujukan untuk mendukung pelaksanaan visi misi RPJPN, RPJMN dan RKP. Kementerian PPN/Bappenas. Background Study: Pengintegrasian Kerangka Regulasi dalam RPJMN 2015 - 2019, Direktorat Analisa Peraturan Perundang-undangan Bappenas, Jakarta, 2013, hlm. 56-57

35 Dibandingkan dengan kerangka pendanaan Negara yang terbatas karena hanya sekitar 15-20 persen dari PDB, maka peran Negara sebagai regulator seharusnya lebih besar, atau mencakup 100 persen untuk memfasilitasi, mendorong maupun mengatur perilaku masyarakat dan penyelenggara negara. Artinya peran negara untuk
} 
Praktek penyelenggaraan negara sebagaimana diuraikan di atas, tampak bahwa kebijakan publik dan regulasi seringkali dipandang sebagai sesuatu yang sama, padahal sesungguhnya tidaklah demikian. Thomas R. Dye mendeskripsikan kebijakan publik sebagai segala sesuatu yang dipilih oleh pemerintah untuk melakukan sesuatu atau tidak melakukan sesuatu. ${ }^{36}$ Sedangkan berdasarkan Pasal 1 angka 2 UU No. 12 Tahun 2011 menentukan bahwa Peraturan Perundangundangan adalah peraturan tertulis yang memuat norma hukum yang mengikat secara umum dan dibentuk atau ditetapkan oleh lembaga negara atau pejabat yang berwenang melalui prosedur yang ditetapkan dalam peraturan perundangundangan. Dengan kata lain, regulasi merupakan bentuk formil dari kebijakan pemerintah agar dapat dilaksanakan di masyarakat. Namun demikian, kebijakan pemerintah tidak harus selalu dikonversikan dalam bentuk regulasi. Perbedaan antara kebijakan dan regulasi adalah sebagai berikut:

\section{Bagan 1. Perbandingan Kebijakan dan Regulasi ${ }^{37}$}

\begin{tabular}{|c|c|}
\hline Policy/Kebijakan & Regulasi \\
\hline $\begin{array}{l}\text { Pilihan tindakan di antara sejumlah } \\
\text { alternatif tindakan. } \\
\text { Kebijakan terpilih tidak harus/selalu } \\
\text { menjadi norma regulasi. } \\
\text { Bebas norma. }\end{array}$ & $\begin{array}{l}\text { Instrumen operasional untuk tindakan } \\
\text { yang terpilih. } \\
\text { Regulasi selalu bersubstansikan } \\
\text { kebijakan. } \\
\text { Terikat norma Sistem Regulasi Nasional, } \\
\text { e.g. strata regulasi (tidak boleh ada } \\
\text { konflik norma), harus konsisten dan } \\
\text { harmonis dengan norma lain, dsb. } \\
\text { Perlu kontrol dari aspek perencanaan } \\
\text { kebijakan, koordinasi, monitoring, dan } \\
\text { evaluasi. }\end{array}$ \\
\hline
\end{tabular}

Belum dipahaminya perbedaan dan hubungan antara kebijakan dan regulasi ini terlihat dari tingginya tingkat dependensi lembaga-lembaga maupun unit-unit sektor terhadap biro atau bagian hukum dalam hal pembentukan regulasi, baik dalam tingkat daerah maupun pusat.

\footnotetext{
memastikan sinergi antara kebijakan pembangunan prioritas dengan kerangka regulasi yang berkualitas, sederhana, tertib dan proses yang transparan akan dapat meminimalisir inefisiensi pelaksanaan pembangunan, nasional, menciptakan good governance serta mencegah praktik korupsi, kolusi dan nepotisme. Ibid., hlm. 58

36 Thomas R. Dye, Understanding Public Policy, Pearson, London, 2016, hlm. 129

37 Kementerian PPN/Bappenas, Backeground Study: Pengintegrasian Kerangka Regulasi dalam RPJMN 2015 2019.., Op. Cit, hlm. 59
} 
Beberapa biro/bagian hukum Sekretariat Daerah (SETDA) provinsi/kabupaten mengeluhkan rendahnya kemauan Satuan Kerja Perangkat Daerah (SKPD) untuk berkontribusi dalam substansi peraturan daerah yang akan dibentuk terkait sektornya. SKPD-SKPD teknis seringkali lebih membebankan pengisian substansi perda tersebut kepada biro/bagian hukum dengan anggapan bahwa persoalan regulasi adalah semata-mata merupakan urusan serta tugas pokok dan fungsi biro/bagian hukum, tanpa menyadari bahwa regulasi bersubstansikan kebijakan yang tentu substansinya lebih dikuasai oleh SKPDSKPD teknis terkait. ${ }^{38}$ Pada tingkat pusat pun kurangnya pemahaman atas kebijakan dan regulasi ini juga terjadi. Dalam proses pembentukan undangundang, kewenangan untuk melakukan harmonisasi ada pada Ditjen Peraturan Perundang-undangan Kemenkumham. Padahal proses harmonisasi seharusnya bukan hanya dilakukan dengan mengharmonisasikan pasal-pasal dalam rancangan undang-undang yang sedang diharmonisasi (baik antar pasal dalam rancangan undang-undang itu sendiri maupun dengan pasal-pasal dalam berbagai undang-undang lain yang terkait), melainkan yang terpenting adalah harmonisasi kebijakan-kebijakan dalam rancangan undang-undang dimaksud dengan kebijakan-kebijakan lain yang mungkin telah ada sebelumnya. ${ }^{39}$

Contohnya, dalam banyak kasus, regulasi bermasalah disebabkan oleh muatan kebijakan (policy) yang bermasalah juga. Seperti tampak pada kasus antara UU No. 25 Tahun 2007 Tentang Penanaman Modal dengan PP Nomor 1 Tahun 2007 Tentang Fasilitas Pajak Penghasilan untuk Penanaman Modal di Bidang-Bidang Usaha Tertentu dan/atau di Daerah-daerah Tertentu. Pasal 1 angka 1 UU Penanaman Modal menyatakan bahwa: "Penanaman Modal adalah segala bentuk kegiatan menanam modal, baik oleh penanam modal asing untuk melakukan usaha di wilayah negara Republik Indonesia". Sedangkan PP Nomor 1 Tahun 2007, yang merupakan salah satu peraturan pelaksanaan UU Penanaman Modal menyatakan bahwa: "Penanaman modal adalah investasi berupa aktiva tetap berwujud tanah yang digunakan untuk kegiatan utama usaha, baik untuk penanaman modal baru maupun perluasan dari usaha yang telah ada". Dalam

\footnotetext{
38 Ibid

${ }^{39}$ Ibid., hlm. 60
} 
kasus ini, terjadi inkonsistensi kebijakan, di mana Penanaman Modal pada kedua peraturan tersebut memiliki pengertian yang sangat berbeda, di mana UU Penanaman Modal mendefinisikan Penanaman Modal sebagai suatu kegiatan, sedangkan PP Nomor 1 Tahun 2007 mendefinisikan Penanaman Modal sebagai investasi berupa aktiva tetap berwujud tanah. Inkonsistensi pengertian Penanaman Modal ini tentu akan menimbulkan kesulitan dalam pelaksanaan undang-undang dan PP tersebut. Sementara dari sisi regulasi, sesungguhnya tidak bermasalah, dalam arti pengaturan mengenai fasilitas pajak penghasilan untuk penanaman modal di bidang-bidang usaha tertentu dan/atau di daerah-daerah tertentu memang seharusnya diatur dalam bentuk peraturan pemerintah sebagai pelaksanaan UU No. 25 Tahun 2007 tentang Penanaman Modal.

Kasus lain terjadi antara UU No. 25 Tahun 2007 tentang Penanaman Modal Pasal 22 ayat (1) huruf a dengan UU Nomor 5 Tahun 1960 tentang Pokok-Pokok Ketentuan Agraria (UUPA) Pasal 29 di atas. Dalam Pasal 22 ayat (1) huruf a UU Penanaman Modal dinyatakan bahwa "Hak Guna Usaha dapat diberikan dengan jumlah 95 tahun dengan cara dapat diberikan dan diperpanjang di muka sekaligus selama 60 tahun dan dapat diperbarui selama 35tahunll, sedangkan Pasal; 29 UUPA mengatur bahwa: “(1) Hak Guna Usaha diberikan untuk waktu paling lama 25 tahun; (2) Untuk perusahaan yang memerlukan waktu yang lebih lama dapat diberikan hak guna usaha untuk waktu paling lama 35 tahun; (3) Atas permintaan pemegang hak dan mengingat keadaan perusahaannya, jangka waktu yang dimaksud dalam ayat (1) dan (2) pasal ini dapat diperpanjang dengan waktu paling lama 25 tahun. Dalam kasus ini, justru regulasinya yang bermasalah. Pengaturan jangka waktu pemberian Hak Guna Usaha yang lebih panjang (paling lama 95 tahun) daripada pengaturan dalam UUPA (paling lama 60 tahun) dimaksudkan untuk meningkatkan daya saing Indonesia di bidang investasi. Namun demikian, kebijakan tersebut diatur secara tidak tepat, karena berada dalam regulasi yang sederajat yakni sesama undang-undang, tanpa mencabut ketentuan dalam undang-undang sebelumnya yang mengatur mengenai hal yang sama (UUPA). Hal inilah yang menimbulkan disharmoni regulasi dan pasti akan memicu permasalahan dalam pelaksanaannya. 
Uraian di atas menunjukkan, bahwa terdapat indikasi kurangnya pemahaman penyelenggara pemerintahan terhadap perbedaan dan hubungan antara kebijakan dan regulasi. Penataan pemahaman sinergi ini merupakan pokok permasalahan yang harus diselesaikan, mengingat kebijakanlah yang selalu menjadi substansi regulasi. Kapasitas para legal drafter dalam memahami kebijakan-kebijakan yang akan menjadi substansi inti regulasi akan sangat menentukan kualitas regulasi yang dihasilkan. Keadaan saat ini, para legal drafter belum cukup memiliki kapasitas yang memadai dalam memahami kebijakankebijakan yang menjadi inti substansi regulasi, sehingga dalam menganalisis draft regulasi yang akan dibentuk, biasanya hanya dengan melihat dari sisi teknis legal draftingnya saja. ${ }^{40} \mathrm{Hal}$ ini tentu saja akan sangat berpotensi memunculkan regulasiregulasi yang bermasalah, karena pembentukan regulasi dilakukan tanpa melalui assessment yang memadai apakah kebijakan yang dioperasionalkan dengan regulasi tersebut memang benar-benar sesuai dengan kebutuhan dan dinamika sosial masyarakat serta tidak menimbulkan permasalahan baru dalam pelaksanaannya. ${ }^{41}$

Perumus kebijakan dan perancang regulasi perlu menguatkan kapasitasnya, mengingat kemampuan analisis dan harmonisasi kebijakan memerlukan pengetahuan yang mendalam mengenai kebijakan-kebijakan yang dituangkan dan akan dioperasionalkan dengan regulasi tersebut. ${ }^{42}$ Sedangkan sampai dengan saat ini, Kemenkumham bukanlah institusi yang memiliki pengetahuan mendalam mengenai berbagai kebijakan sektoral. Penguatan kapasitas perumus kebijakan

\footnotetext{
40 Seringkali legal drafter menurut telaahan BPHN belum mampu menggunakan prinsip lex specialis derogat legi generalis ataupun prinsip lex posteriori derogat legi priori dengan baik, penggunaan prinsip tersebut sangat bergantung pada siapa yang menggunakan dan menafsirkannya. Badan Pembinaan Hukum Nasional, Perencanaan Pembangunan Hukum Nasional 2015-2019, Kementerian Hukum dan HAM, Jakarta, 2014, hlm. 60-61

${ }^{41}$ Menurut Bappenas rendahnya kualitas regulasi di Indonesia juga disebabkan rendahnya apresiasi terhadap proses (prosedur) perumusan kebijakan. Kebijakan yang merupakan substansi inti regulasi, sesungguhnya memerlukan analisis dan identifikasi yang mendalam sebelum dipilih dan dirumuskan. Rendahnya apresiasi terhadap proses pemilihan dan perumusan kebijakan ini terlihat dari belum dilakukannya Cost Benefit Analysis (CBA) dan Cost Effectiveness Analysis (CEA) sebelum suatu kebijakan diputuskan. CBA/CEA terhadap kebijakan ini sangat penting dilakukan, sehingga ketika dioperasionalkan dalam bentuk regulasi akan benar-benar mendatangkan lebih banyak manfaat daripada biaya, baik bagi negara maupun masyarakat pada umumnya. Kementerian PPN/Bappenas, Background Study: Pengintegrasian Kerangka Regulasi dalam RPJMN 2015 - 2019..., Op. Cit., hlm. 70

${ }^{42}$ Menurut penelitian Bappenas mengenai reformasi regulasi, peningkatan pemahaman dapat dilakukan dengan upaya peningkatan kualitas sumber daya manusia pembentuk regulasi (perumus kebijakan dan perancang regulasi) agar menghasilkan regulasi yang mampu melihat dimensi kenegaraan secara lebih luas (bentuk negara kesatuan, keberagaman/ pluralisme, dan sebagainya) dalam perumusan kebijakan dan pembentukan regulasi. Ibid
} 
dan perancang regulasi dapat dilakukan pada tahap proses kajian, penelitian maupun penyusunan normanya, dengan menata koordinasi antara kementerian pengusul dengan kementerian/lembaga yang berwenang melakukan harmonisasi. Sehingga, ketika rancangan regulasi yang dibutuhkan telah selesai disusun, tidak lagi memerlukan proses harmonisasi.

Peningkatan apresiasi terhadap proses (prosedur) pembentukan regulasi juga merupakan salah bentuk penguatan kapasitas perumus kebijakan dan perancang regulasi. Hal ini dapat dilakukan dengan mengadakan pertemuan-pertemuan yang bersifat koordinatif antarkementerian/lembaga, khususnya yang berfungsi sebagai wadah koordinasi antarsektor guna menyinergikan kebijakan-kebijakan antarsektor (interdept). Rendahnya apresiasi ini tampak dari kurangnya kemauan sektor pengusul rancangan regulasi, untuk secara kontinyu mengikutsertakan sektor-sektor terkait dalam proses-proses koordinasi pembentukan regulasi. Hal inilah yang seringkali mengakibatkan regulasi yang baru dibentuk langsung mendapatkan tentangan dari sektor lain yang merasa dirugikan. Selain itu, pihak yang diwakili untuk ikut berpartisipasi dalam pembahasan-pembahasan regulasi seringkali dihadiri oleh wakil yang berganti-ganti atau pihak yang tidak berwenang mengambil keputusan (bukan decision makers) tanpa adanya transfer of knowledge.

Peningkatan kapasitas dapat juga dilakukan dengan memberdayakan pelaksanaan konsultasi publik, atau yang dalam UU No. 12 Tahun 2011 disebut dengan partisipasi masyarakat. Lothar Gundling mengemukakan beberapa alasan tentang perlunya peran serta masyarakat dalam penyusunan kebijakan, antara lain: a. informing the administration (memberikan informasi kebutuhan hukum secara sosiologis kepada pemerintah), b. increasing the readiness of the public to accept decisions (meningkatkan kesediaan masyarakat untuk taat kepada kebijakan negara), c. supplementing judicial protection (memberikan jaminan perlindungan hukum), d.democratizing decision-making (mendemokrasikan pengambilan keputusan). ${ }^{43}$ Namun hingga saat ini, konsultasi publik yang dilakukan seringkali

${ }^{43}$ Lothar Gundling, Public Participannt in Environmental Decision Making, dalam Trends in Environmental Policy and law, IUCN. Gland, Switzerland, 1980, hlm. 19-21 
masih sebatas formalitas untuk pemenuhan ketentuan Pasal 96 UU No. 12 Tahun 2011 tanpa mekanisme konsultasi publik yang jelas, khususnya mengenai mekanisme pengawalan dan akomodasi masukan-masyarakat dalam proses pembentukan regulasi.

Bappenas bahkan mengemukakan ketidaksetujuannya terhadap pelaksanaan naskah akademik suatu rancangan regulasi diserahkan oleh kalangan perguruan tinggi. Kecenderungan untuk menyerahkan penyusunan naskah akademik suatu rancangan regulasi, khususnya undang undang pada pihak ketiga, terutama kepada perguruan tinggi menunjukan kurangnya kapasitas perumus kebijakan dan perancang regulasi. Kata akademik seolah menjadi justifikasi untuk menyerahkan penyusunan naskah akademik kepada pihak perguruan tinggi. Pandangan ini juga didukung oleh kalangan legislatif yang cenderung hanya mau menerima naskah akademik yang disusun oleh akademisi, atau setidaknya melibatkan akademisi. Padahal penyelenggara negara sesungguhnya adalah juga merupakan praktisi atas kebijakan-kebijakan yang disusunnya, sehingga seharusnya lebih mengetahui kondisi di lapangan atas pelaksanaan kebijakankebijakan yang telah disusunnya. ${ }^{44}$ Meskipun demikian, penulis beranggapan bahwa penyelenggara negara harus melibatkan pihak perguruan tinggi dalam penyusunan kajian akademik. Kajian akademik lebih memberikan perspektif objektif, dibandingkan penyelenggara negara yang notabene praktisi, karena kebijakan-kebijakannya cenderung tidak mampu sepenuhnya menilai permasalahan objektif apabila tidak dibantu oleh perguruan tinggi. Sehingga kapasitas perumus dan perancang dapat memperoleh penguatan di sisi teoritis yang dapat mengangkat kapasitas perumus dan perancang regulasi.

\section{Penutup}

Berdasarkan hasil penelitian di atas, maka penataan regulasi dapat dilakukan terhadap tiga sektor yaitu simplifikasi regulasi, rekonseptualisasi pemahaman mengenai kebutuhan regulasi, dan penciptaan sinergi antar pembentuk regulasi. Simplifikasi dapat dilakukan dengan penciptaan database peraturan perundangundangan yang terintegrasi dan sistematis dan melakukan sortir terhadap regulasi

44 Background Study: Pengintegrasian Kerangka Regulasi dalam RPJMN 2015 - 2019..., Op. Cit., hlm. 72 
yang saling berkonflik, inkonsisten, multitafsir, dan tidak operasional. Rekonseptualisasi pemahaman mengenai kebutuhan regulasi, dilakukan dengan tidak merespon atau bereaksi atas penyelesaian persoalan yang selalu berujung pada pembuatan regulasi baru. Penciptaan sinergi antar pembentuk regulasi dilakukan dengan penguatan kapasitas perumus kebijakan dan perancang regulasi dan peningkatan apresiasi terhadap prosedur penyusunan regulasi.

\section{Daftar Pustaka}

\section{Buku}

Anggono, Bayu Dwi, Perkembangan Pembentukan Undang-Undang di Indonesia, Konstitusi Press, Jakarta, 2014.

Dye, Thomas R. Understanding Public Policy, Pearson, London, 2016.

Gundling, Lothar, Public Participannt in Environmental Decision Making, dalam Trends in Environmental Policy and law, IUCN Gland, Switzerland, 1980.

Hartono, Sunaryati, Analisis dan Evaluasi Peraturan Perundang-undangan Peninggalan Kolonial (Belanda dan Jepang), Kementerian Hukum dan Hak Asasi Manusia, Jakarta, 2014.

Locke, John, Second Treatise of Civil Government, McMaster University Press, Dublin, 1998.

Marušić, Andreja dan Radulović, Branko, Regulatory Impact Analysis (RIA) Manual, USAID Montonegro, Podgorica, 2011.

Sadiawati, Diani, et al. Strategi Nasional Reformasi Regulasi: Mewujudkan Regulasi yang Tertib dan Sederhana, Kementerian Perencanaan dan Pembangunan Nasional/ Bappenas, Jakarta, 2015.

Seidman Ann, Seidman, Robert, dan Abeyserkere, Nalin, Penyususnan Rancangan Undang-Undang Dalam Perubahan Masyarakat Yang Demokratis, Elips Departemen Kehakiman dan Hak Asasi Manusia, Jakarta, 2002.

Wahjono, Padmo, Sistem Hukum Nasional dalam Negara Hukum Pancasila: Pidato Ilmiah pada Peringatan Dies Natalis Universitas Indonesia ke- 33, Rajawali Press, Jakarta, 1983.

\section{Hasil Penelitian}

Badan Pembinaan Hukum Nasional, Perencanaan Pembangunan Hukum Nasional 2015-2019, Kementerian Hukum dan HAM, Jakarta, 2014.

Kementerian Hukum dan Hak Asasi Manusia, Pengharmonisasian, Pembulatan, dan Pemantapan, Konsepsi Rancangan Peraturan, Perundang-Undangan, Direktorat Jenderal Peraturan Perundang-Undangan, Jakarta, 2010. 
Kementerian PPN/Bappenas. Background Study: Pengintegrasian Kerangka Regulasi dalam RPJMN 2015 - 2019, Direktorat Analisa Peraturan Perundangundangan Bappenas, Jakarta, 2013.

\section{Jurnal}

Chandranegara, Ibnu Sina, "Purifikasi Konstitusional Sumber Daya Air Indonesia", Jurnal Rechtsvinding, Vol. 5 No. 3, 2016.

Hartono, Darminto dan Soekotjo Hardiwinoto, "Legal Perspective on Asean Economic Community”, Diponegoro Law Review, Vol. 3, No. 2, 2018.

Malau, Masnur Tiurmaida, "Aspek Hukum Peraturan dan Kebijakan Pemerintah Indonesia Menghadapi Liberalisasi Ekonomi Regional: Masyarakat Ekonomi ASEAN 2015", Jurnal Rechtsvinding, Vol. 3, No. 2 Tahun 2014.

Suska, "Prinsip Regulatory Impact Assessment dalam Proses Penyusunan Peraturan Perundang-Undangan Sesuai UU Nomor 12 Tahun 2011", Jurnal Konstitusi, Volume 9, Nomor 2, Juni 2012

Susskind, Richard, "Legal Informatics: a Personal Appraisal of Context and Progress", European Journal of Law and Technology, Vol. 1, No. 1, 2010.

\section{Disertasi}

Matthias, Dejonghe, "Constitutional Courts: Democracy vs. Juristocracy?", Disertasi pada Fakultas Hukum Universitas Genht, Brussel, 2015.

\section{Makalah/Pidato}

"Penyusunan Program dan Strategi Reformasi Regulasi dalam Rangka Memperkuat Substansi dan Operasionalisasi UU Nomor 12 Tahun 2011" Focus Group Discussion yang digelar oleh Kementerian Hukum dan HAM di Bogor, tanggal 26-28 Oktober 2016.

\section{Artikel Koran}

Seputar Indonesia, 12 November 2015, Nasir Djamil, “Setengah Hati Reformasi Regulasi."

Kompas, 13 Maret 2017, Saldi Isra, "Merampingkan Regulasi."

Kompas, 13 Maret 2016.

\section{Peraturan Perundang-undangan}

Undang-Undang Nomor 5 Tahun 1960 tentang Pokok-Pokok Agraria, Tambahan Lembaran Negara Nomor 2043.

Undang-Undang Nomor 12 Tahun 2011 Tentang Pembentukan Peraturan Perundang-undangan, Lembaran Negara Republik Indonesia Tahun 2011 Nomor 82, Tambahan Lembaran Negara Republik Indonesia Nomor 5234.

Undang-Undang Nomor 23 Tahun 2014 Tentang Pemerintahan Daerah, Lembaran Negara Republik Indonesia Tahun 2014 Nomor 244, Tambahan Lembaran Negara Republik Indonesia Nomor 5587. 
Undang-Undang Nomor 36 Tahun 2009 tentang Kesehatan, Tambahan Lembaran Negara Republik Indonesia Nomor 5063.

Undang-Undang Nomor 18 Tahun 2014 tentang Kesehatan Jiwa, Lembaran Negara Republik Indonesia Nomor 185, Tahun 2014.

Undang-Undang Nomor 25 Tahun 2007 Tentang Penanaman Modal, Lembaran Negara Republik Indonesia Tahun 2007 Nomor 67; Tambahan Lembaran Negara Republik Indonesia Nomor 4724.

Peraturan Pemerintah Nomor 1 Tahun 2007 Tentang Fasilitas Pajak Penghasilan untuk Penanaman Modal di Bidang-Bidang Usaha Tertentu dan/atau di Daerah-daerah Tertentu, Tambahan Lembaran Negara Republik Indonesia Nomor 4675.

Peraturan Menteri Kelautan dan Perikanan Nomor 2 Tahun 2015 tentang Larangan Menangkap Ikan Menggunakan Alat Tangkap Cantrang, Berita Negara Republik Indonesia Tahun 2015 Nomor 31.

\section{Putusan Pengadilan}

Putusan Mahkamah Konstitusi Nomor 2-3/PUU-V/2007. 